論文

\title{
森林環境譲与税を契機とした都道府県による市町村支援の方向性の分析 一使途整理・情報交換・組織設置に関する全国の比較から一
}

\author{
香坂 玲*,1 $・$ 内山愉太范
}

\begin{abstract}
2019 年度に導入された森林環境譲与税（以下, 環境譲与税）について, 市町村は森林管理に関わり, 税の使途も公表しなけ ればならない。一方で市町村では受け皿の人材が不足しており, 都道府県の支援が重要となる。本研究では, 都道府県レベル において(1)環境譲与税と府県単位の独自の超過課税（以下，県環境税）の使途の整理状況，(2) 2020 年度前後に設置された市町 村支援の組織・会議体，(3)人事交流，(4)独自のガイドラインに着目して分析を行った。そもそも県環境税は各県に使途や背景 に差異があり，全体比較には自ずと限界があるものの，二制度のすみ分けは主に間伐等の物理的な森林整備において府県間で 対応が異なること等が特定された。支援では 6 県が独自にセンターを設置し, 10 府県が人事交流を実施し, 県の普及員と市町 村の職員を併任する制度を独自に導入した特徵的な事例（愛媛県）も存在した。17府県が森林経営管理制度または環境譲与税 の独自のガイドラインを作成していた。41府県を対象とした定量分析では情報交換の会の設置状況は市町村数や私有林人工林 面積率と相関があり，人事交流及びガイドラインの策定状況は譲与額との相関があった。 キーワード：都道府県，森林環境譲与税，森林環境税
\end{abstract}

\begin{abstract}
Ryo Kohsaka, ${ }^{* 1}$ Yuta Uchiyama*,1 (2021) Forest Environment Transfer Tax, Prefectural Forest Policy, and Support for Municipalities. J Jpn For Soc 103: 134-144 Forest environment transfer tax at the national level and the accompanying implementations of forest management schemes were introduced in Japan in 2019. Local governments of both prefectures and municipalities receive the tax revenue and need to disclose how the revenue was used annually. There are existing forest tax schemes in 37 prefectures, and prefectural governments are in need to demarcate and elucidate the uses of their prefectural taxes and the national-level tax. In this study, surveys were conducted to detect (1) demarcation of uses of the prefectural taxes and national-level tax in individual prefectures, (2) information exchange meetings of municipalities in individual prefectures and supporting bodies, (3) exchange of staff members and (4) guidelines for new management systems. Although there is a general limitation of comparing prefectures with different contexts and prefectural tax schemes, it was identified for (1), demarcation methods of uses of the prefectural taxes and national-level tax in forest management such as thinning differ among prefectures. There was diversity in patterns for (2) and six prefectures established new permanent bodies for supporting municipalities. For (4), exchanges of staff members between prefectural and municipalities were identified. In Ehime Prefecture, prefectural staff were serving as extension workers of both prefectures and municipalities simultaneously, as a newly introduced system in the prefecture. For (4), guidelines were developed in 17 prefectures. Furthermore, implementation of information exchange meetings correlates with the number of municipalities and ratio of private forest, and exchanging of staff members and developing guidelines correlate with the amount of the allocated forest environment transfer tax.
\end{abstract}

Key words: Prefectures, Forest Environment Transfer Tax, Forest Environmental Tax

\section{I. は じめ に}

\section{1. 森林環境譲与税と都道府県の役割}

国，都道府県，市（横浜市の例）の各層において森林の 維持や整備のための税を導入する際には, 各税で対象林の 所有形態や経営に向けた目的などに相違はありつつも，大 半の場合において「森林の公益的機能」とその維持が根拠 となってきた。例えば 2018 年の税制改正大網では，森林 環境税及び森林環境譲与税（以下, 環境譲与税）創設の趣 旨として，パリ協定を含む吸収源対策と災害防止等が序文 で言及されている。多くの県レベルの森林整備のための超 過税（以下, 県環境税) の背景でも, 防災, リクリエーショ ン機能と，それを次世代へ継承する必要性が言及されてい る。税の導入・運営に際して,「森林の公益的機能」は納 税者（国民・県民・市民）の理解が得られやすい反面，各 層における税の使途と役割や機能の整理も重要となる。

2019 年に導入された環境譲与税は, 手入れ不足の, 経 営管理が行われていない民有林の改善と上述の森林の機能
の公益性の維持を目的とした国レベルの制度であり，市町 村と都道府県に対して客観的な基準で按分して譲与されて いる。譲与額の算定には次の三変数が用いられている：私 有林人工林面積 $(5 / 10)$, 林業就業者数 $(2 / 10)$, 総人口 $(3 / 10)$ 。 環境譲与税は，これまでの施策や予算措置では対応できな かった施策に充当されるものとして位置づけられている。 環境譲与税の使途は, 市町村に扔いては森林整備及びその 促進に関する費用に充てること, 都道府県においては森林 整備を実施する市町村の支援等に関する費用に充てること と，それぞれに対し大まかな方針が提示されている。具体 的な使途については, 各市町村に一定の裁量が委极られて いる一方で, その使途についての公表と説明の責任も市町 村が負うこととされている。都道府県については, 初年 度の 2019 年度は譲与額全体の 2 割, 2024 年度までに 1 割 まで比率を段階的に下げるかたちで配分がなされる。全国 の都道府県と市町村の双方への配分額の合計額は, 初年度 は 200 億円であり， 2024 年度に 600 億円までの増額が予 定されている。

*連絡先著者 (Corresponding author) 香坂 玲 E-mail: kohsaka@hotmail.com (D) https://orcid.org/0000-0001-6822-4340, 内山愉太 E-mail: yutanu4@gmail.com (D) : https://orcid.org/0000-0001-7363-896X

1 名古屋大学大学院環境学研究科 $\bar{T} 464-8601$ 愛知県名古屋市千種区不老町 D2-1 (Graduate School of Environmental Studies, Nagoya University, Furo-cho, Chikusa-ku, Nagoya, Aichi 464-8601, Japan)

(2020 年 8 月 24 日受付 ; 2021 年 1 月 27 日受理) 
市町村と都道府県の現場では, それぞれ森林をめぐる環 境条件や社会・経済的な状況が大きく異なる。森林整備や 林業振興に必要な対応も, 都道府県・市町村がおかれてい る状況ごとに検討する必要がある。環境譲与税の主な譲与 対象は市町村であるが, 市町村レベルでは, 税の受け皿と して計画の推進役を担う林務の専門的知識を有する職員が 都道府県より不足している状況もあり（鈴木ら 2020），都 道府県等による支援のあり方が課題となっている。

既存研究では，市町村の支援を含め，一定の役割を担う 都道府県を対象に，2019 年度前半の方針を中心とした初 期の環境譲与税の使途についての分析が行われている（香 坂・内山 2019)。環境譲与税導入の初年度が終了した段階 で，県環境税を導入している府県において，環境譲与税と 県環境税の間でどのような使途の整理がなされたのか，ま た，市町村支援の詳細については，いまだ調查分析されて おらず課題となっている。本研究では, このような課題を 踏まえ, 導入の初年度を終えた時点における国の環境譲与 税と 37 の府県で森林整備等のために独自に導入されてい る県環境税の使途の整理状況と, より広範囲に情報交換・ 人事交流・支援組織の設置という各観点から市町村支援に ついて分析を行う。

\section{2. 森林環境譲与税の概況}

まず環境譲与税の概況を把握したうえで都道府県の類型 を提示することとする。試論的に譲与額と木材生産産出額 を基に，都道府県を四つのグループに分ける（図-1）。

全体として, 実際譲与額は木材生産産出額と相関があり, 概ね木材生産産出額からみた林業振興の観点からも潜在的 に森林整備を必要としていると想定される県に，より大き な譲与額が配分されている。これは私有林人工林面積, 林 業就業者数で譲与基準の 7 割を占めていることから予想で きる結果となっている。一方で残りの 3 割を占める人口が 影響している類型（後述するグループ B）も存在する。

木材生産産出額と環境譲与税の双方が特に高いのが北海 道(図のグループD), 逆に双方ともに特に低いのが香川県・
沖縄県（グループ A）である。環境譲与税の配分には人口 も考慮されることから贈与額は比較的大きいが，木材生産 産出額は低く, 回帰曲線の下側に位置するのが東京都, 大 阪府，神奈川県（グループ B）である。そして大多数の府 県が, 木材生産産出額と環境譲与税の緩やかな回帰曲線の 付近に存在し, 図の中心部分に密集しているグループ C に該当する。また，独自に県環境税を導入している 37 府 県のうち, 大阪府と神奈川県を除く大多数の 35 府県がグ ループCに含まれている。

東京都や神奈川県のような木材産出額は大きくなく, 非 林業県として分類され得るグループ B について, 人口が 効いて一定程度の譲与がなされていることにも注意する必 要がある。具体的には, 都市部を中心に木材利用促進, 普 及啓発にも支弁できるスキームとなっており，直接的な森 林整備のみならず，木材利用の促進等を通した間接的な森 林整備も推進されることが期待されている（石崎 2019 ; 香坂ら 2020 ; 内山・香坂 2020)。また, 職員の人件費に ついては, 各自治体において人的資源の不足が指摘されて いるなかで, 関連制度への対応という観点からの人員, 体 制の補強としては環境譲与税で支弁可能である。また, 使 途については前述の通りインターネットで公開される。こ のように, 地方譲与税としての環境譲与税は, 森林整備を 直接, 間接的に促進する施策の財源として, 都道府県と市 町村が連携するかたちで活用されている。

本研究では, 環境譲与税と県環境税の使途の整理につい て分析を行ったうえで, 都道府県の市町村への支援の体制 に違いや傾向があるのかどうか，具体的には支援体制のべ ンチマークとして連絡・連携の形態, 人事交流, ガイドラ イン・手引き等について分析をする。なお， III.5.の定量 的なデータを用いた統計分析では, 独自に県環境税を導入 している府県の大多数が含まれ, 全国的な平均像に近いグ ループCの府県を対象とした。

\section{3. 森林環境譲与税の活用をめぐる現状と課題}

2018 年の税制改定大綱では, 環境譲与税の創設は, パ

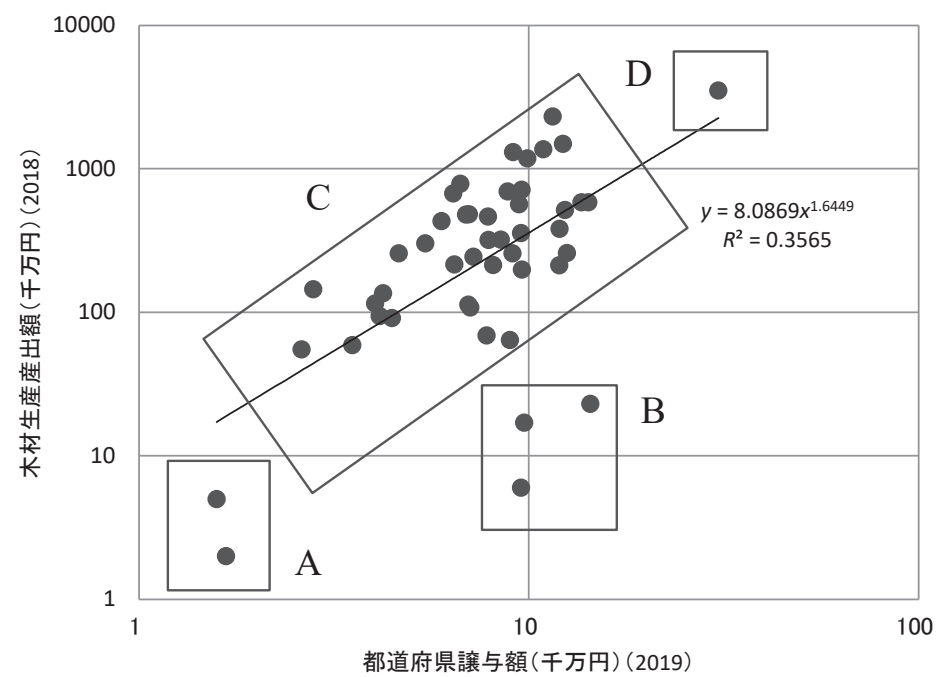

図-1. 環境譲与税の都道府県への配分額と木材生産産出額の相関関係 木材生産産出額については農林水産省の統計情報「平成 30 年林業産出額」を, 環 境譲与税の都道府県への配分額については総務省「令和元年度 森林環境譲与税 譲 与額」を参照した。 
リ協定などの地球規模環境課題に加え, 2018 年 5 月の森 林経営管理法の成立を踏まえるものとしている。その新法 成立に伴い, 2019 年 4 月よりスタートした森林経営管理 制度のなかでは, 林業経営に適した森林と適さない森林を 区分したうえで，後者を中心に市町村自らも管理を行う内 容となっている。

税制改定大綱において, 森林経営管理法の成立が税導入 の背景として言及されているなかで，市町村等には公開に よる使途の説明が求められる。一方で, 環境譲与税の活用 については，事実上，市町村に裁量が大きく任せられてい る。後述するように，その使途と目的を巡っては，都道府 県, 市町村, 関係団体ごとに解釈に差がみられる, あるい は想定する使途や運営に対する共通理解の形成の途上にあ るのが現段階での実情といえよう。そうした課題を抱えな がらも, 環境譲与税の創設は, 国, 都道府県, 森林組合と いう既存のアクターに加え，多くの市町村が，新たな財源 としての環境譲与税を踏まえた森林管理への関与を構想す る契機となっている。これまで先進的な自治体や森林組合 の取り組みとしてなされてきた私有林の集約化・団地化等 を含む管理（松本 2018）が，全国的に促進されることが 期待されている。

市町村は，森林整備におけるより積極的な役割が期待さ れているが，市町村や都道府県の森林と林業の状況は多様 である（多田 2020）。人的・予算的な制限もあり，受け具 として機能することに困難を抱えている自治体もある（鈴 木ら 2020)。特に人的リソースの不足について即効性のあ る技術的な解決策を提示することは困難であり，構造的な 問題が指摘されている（柿澤 2018）。自治体の自主的な取 り組みを促進するには，各自治体のキャパシティを踏まえ た活用の方向性を議論する必要がある（西尾 2018）。鈴木 ら（2020）は，608 の市町村による環境讓与税への受け止 め方として，「独自の森林予算が増えるので歓迎」(40\%) と回答している一方で,「事務負担が増えるので迷惑」 (30\%)，「都道府県が実施すべき」（22\%）という否定的な 受け止められ方がある実情を報告している。自治体はイン ターネットの利用等により環境譲与税の使途を公表しなけ ればならないこととされているが，環境譲与税の使途の具 体的な線引や方針は各自治体が決定する必要があるため, 使途の設定や説明が負担感を与えている側面もある。後述 するように，府県が独自に環境譲与税と県環境税の使途の 区分について手引や方針を発表しているケースもある。

県環境税と環境譲与税の府県配分分の使途の区分,「す み分け」の必要が生じた背景としては，そもそも順番とし て県環境税が国の制度よりも先に, 各府県で時期や目的が 必ずしも統一されずに導入されてきた経緯がある。結果, 県環境税は国レベルの環境譲与税の導入を前提とせずに設 計されており，府県によっては目的や使途に幅がある形で 設定されている場合もある。

つまり, 環境譲与税の主な使途として手入れ不足の私有 林人工林の整備 (それが難しい場合などは木材利用の促進) が想定されているが，県環境税の使途や市町村との連携事 業において，県環境税によっては必ずしも明確な差異がな
い場合もあったため, 情報の整理, あるいは使途のすみ分 けの必要が生じた。清水（2019）は, 重複に注意する背景 について三点挙げており，府県民への説明責任から両税か ら同じ事業項目が実施されないこと, 環境譲与税では既存 の林業関連事業費を減らさずに新しい事業展開をしなけれ ばならないこと, 県環境税を活用した市町村事業で重複を 発生させないこととしている。一点目の説明責任に関連し， 使途の説明責任を果たすためにインターネット上などで環 境譲与税の使途の公開が自治体に求められている。専門家 ではない一般人にも分かりやすい形で, 県環境税と環境譲 与税の区分を伝える必要性が生じていることも影響があ る。説明については, 混同を避ける意味で名称変更等の事 務的な「すみ分け」の必要性が生じたケースもあると推察 される $(2020$ 年 4 月の鹿児島県の「森林環境税」から「み んなの森づくり県民税」への名称変更など）。

制度設計の当初は, 国レベルの森林環境税の徵収が始ま る 2024 年度まで, 環境譲与税の譲与は交付税特別会計に おける譲与税財源の借入れを行うスキームであったため, 諨与と徵収のタイミングが異なっていた。ただし環境譲与 税導入直後の 2019 年度に, 財源として地方公共団体金融 機構の公庫債権金利変動準備金を活用し, 交付税特別会計 にて譲与税財源の借入れをしないこととしたうえで，災害 防止及び国土保全機能強化等の観点から森林整備を促進す ることが意図され, 環境譲与税の譲与額を前倒しで増額す るという制度変更がなされた（総務省 2019）。大綱の文言 では, 環境譲与税の変更に関して「自治体における森林整 備と関連施策の実施状況等を鑑みて」, 増額については「災 害防止 - 国土保全機能強化等の観点から, 森林整備を一層 促進するため」と冒頭で言及されている。今後, 制度変更 の政策決定過程，根拠となった災害（都道府県担当者への ヒアリングでは言及), 森林整備の状況, 実施状況の検討 結果やプロセスの公開, 分析も待たれる。また, そのため に地方財政計画に関する国会等に打ける議事録，根拠と なった科学的デー夕等の保管が望まれる。施行して間もな い制度ながら，税を活用する側の自治体のみならず，制度 自体にも変化が生じている。

\section{4. 県環境税及び環境譲与税に関する既存研究}

環境譲与税は比較的新しい制度であるため, 環境譲与税 を直接的に対象とした研究は限定的である。環境譲与税を 対象とした研究は, 制度活用が開始されて間もない現状に おいて制度論的研究が行われている。例えば，受益と負担 の関倸性についての考察（石崎 2019 ; 飛田 2019; 吉弘 2020a，b）や，国民に納税負担を求め，それを財源として市 町村自らが私有林の整備を行うことが可能となるという制度 の新規性の指摘（田家 2018）などがあり，本研究も課題と して指摘する「市町村がそれぞれの状況に応じて譲与税を 活用すること」や，県環境税とのすみ分けについて指摘し ている研究（田家 2019 ; 淺田・阿部 2020）もある。環境 譲与税の活用状況に関する実証的研究は, 県環境税導入府 県を対象とした研究 (香坂・内山 2019) や, 市町村レベル の都市・農山村連携（香坂ら 2020）, 政令市の動向に着目 した研究 (内山・香坂 2020), 各地の環境条件を踏まえた 
自治体の取り組みの多様性と課題の分析（多田 2020）等が あり, メタレベルの分析として前節で引用した自治体職員の 意識調查（鈴木ら 2020）がある。環境譲与税の活用状況に 関する研究は, いずれも制度導入の初期段階において, 主 に各地に打ける多様な取り組及状況を報告している。

これまでに蓄積された県環境税に関する研究において導 出された示唆は, 環境譲与税の分析においても有効なもの が含まれるため, 県環境税のみを対象とした研究について もレビューを行った。その結果, 既存研究について次の三 つの分類が見出された；(1)制度導入経緯・活用状況，(2) 制度の効果, (3) 納税者意識。以下では (1)〜 (3)について 既存の議論を整理しつつ, 本研究の位置づけを示す。

(1) 制度導入経緯・活用状況に関する研究については, 高橋（2005）をはじめとして, 各地における県環境税の導 入経緯と, 活用状況が分析されている。例えば, いわての 森林づくり県民税」検討委員会についての分析（岡田 ら 2007）や, 高知県での政策決定過程分析（竹本 2009） 等がある。水源林保全に抢ける費用分担の議論を踏まえて 県環境税について考察を行っている石崎（2010）は, 応益 的な負担という方式を採用することが困難であることが各 地に扔ける水源税等の検討を経て見出されたことや, 県環 境税の参加型税制としての特徴等を議論している。県環境 税の税額は, 各地の資源量等を基に決定するのではなく,

主に県民アンケート及び先行導入県の額を基に決定されて いる（花岡 2011）。県民が納得感を持って納税することが 可能な税制度とすべく, 各府県が参加型の形式を取り入れ た結果, 参加型税制としての特徵を有することとなってい る。ただし, 参加型であることは, 各地の森林・林業の状 況が制度に直接的に反映されることには必ずしもつながっ ていない。具体的には, 青木 (2014) が指摘する通り, 県 環境税の導入県のなかで, 他県と大きく異なる税額を設定 することは県民の理解を得られない可能性がある。このよ うに県環境税は, 必ずしも各地の資源量や森林・林業の特 徵等が直接的に税額に反映されていないなかで, 各地にお ける森林整備の必要性を発端として, 県民の「参加」を経 て導入・活用がなされている。

国レベルの環境譲与税の導入 ・活用のあり方は県環境税 と類似しているが, 県環境税の特徵としての参加型の形式 を採用することは, 環境譲与税については困難である。37 府県で県環境税が導入されていることは, 環境譲与税の導 入について国民の理解が得られる可能性があることを示す 根拠の一つとなり得る。ただし, 国レベルで環境譲与税を 導入することについて，国民の間で議論が十分になされた という根拠を見出すことは難しい。このような状況のなか で, 国民の理解を得ながら環境譲与税という制度を運用す るには，都道府県による市町村支援を含む税の活用の実態 を解明し，国民に共有していく必要がある。

(2) 制度の効果については, 森林整備に対する効果と, 地方自治や森林のローカルガバナンスに対する効果を分析 するものがある。前者については, 2000 年代前半を中心 に研究がなされている。森林整備への効果に関する主な示 唆としては, そもそも顕著な効果が得られるような予算規
模となっていないこと（古川 2004 ; 番場 2004 ; 秋 山 2005 ; 今若・佐藤 2008）や, 地域への経済的なインパ クトも小さいことが指摘されている（青木・桂木 2008）。 普及啓発に関する効果検証を行っているものもあるが（佐 藤・山本 2013), 実質的な量としての森林整備への効果よ りも, 地方自治や森林政策を各府県に打いてより重点的に 議論する契機を与えている面が強いと考えられる（高 井 2005 ; 木村 2016)。施業地域の分布について県内の高 齢化率や災害リスクの高い場所の分布との関係について分 析した研究もあるが (Uchiyama and Kohsaka 2016), 他の 補助金等の財源による事業と比較した量的な森林整備への 効果については, 長期的な視点からも評価を行う必要があ ると考えられる。

制度の効果を検討する際に, 県・環境税を生態系サービ スの直接支払い（Payment for Ecosystem Services：PES）の 一種として検討している研究もある (Bespyatko・井 村 2008 ; 曹 2015)。PES の観点からは, 県環境税はサー ビスの供給者に対して直接的補填を行う制度となっていな い点が指摘され，途上国で一般的に導入されている PES とは異なる制度であると考えられる (Bespyatko・井 村 2008)。県環境税は府県によっては税の使途を公開する ことがなされており，それは県民の理解を得るうえで有用 であると考えられる。他方で, 一般的な PES のように受 益と負担が明確でなく，その効果については，地方自治や 森林のローカルガバナンスの向上が主となっている実態が あり, 県民がそのような効果に対して納得しているのか否 かは検証する必要がある。

(3)納税者意識については, 先述の県環境税の効果が, 同税制度を県民が受容するうえで主要な要素となることが 示唆されている（村上 2011）。また，支払い意思に関倸す る要素としては, 地域への愛着等の要素が指摘されており (大石・立福 2013), 地域に対して当事者意識を涵養する ことは, 支払い意思を高めることにつながると考えられる。 環境譲与税の納税者意識については, 同税の効果の検証が 難しい初期段階において如何なる分析が可能であるか検討 する必要がある。国民による熟議を基に導入された制度と は言い難い環境譲与税について, 納税者である国民の理解 を得るには, 同税による事業の活用実態と効果を提示して いく必要があると考えられる。実際, 環境譲与税について は前節で述べた通り使途の公開が義務付けられている。

以上のレビュー結果を踏まえ, 本研究では, 都道府県の 環境譲与税を活用した市町村支援の方針を検討し，県環境 税と環境譲与税の府県配分分の使途の整理等を基に, 国民 の理解を得ていくうえで有用な知見を提示することを目的 とする。本研究は, 都道府県による市町村支援のための環 境譲与税の活用状況に着目している点で, (1)の研究の延 長に位置づけられる。特に, 既存研究（田家 2019 ; 淺田・ 阿部 2020）で指摘されている, 県環境税とのすみ分けに ついても対象とした調查分析結果を提示する。制度間のす み分けの議論は, 行政学及び関連分野の政策評価の文脈に おける類似した議論として, 業務分担の議論はあるが, 既 存研究では対象は制度ではなく, 主に行政の部署が分析対 
象となる（相川 2020；山谷 2005）。さらに，環境譲与税 の特徵として, 都道府県には市町村を支援するために税が 配分されている点に着目し, 都道府県の市町村の支援のあ り方について，意見交換の場の設置，人事交流，ガイドラ インを対象に調査分析を行う。

人事交流に関係する職員の配置については，福島県を対 象に技術系職員 1 人当たりの林業費等が拡大していること を指摘する研究がある（木村 2017）。また，行政学を援用 した相川（2020）においても，岐阜県と長野県の県から市 町村への垂直補完の事例が比較・分析されている。また, 大谷（2017：75）では，「都道府県は政策動向に合わせた 人材をどこからどのようにして確保しているのか」という 問いのもとで，国からの出向と地元組との置き換え等を分 析している。ただ，既存研究では国や都道府県が主眼であ り，「市町村が都道府県から人材をどこからどのように確 保しているのか」という情報に関する知見は蓄積されてお
らず，本研究は林政分野における新制度の導入時における 市町村と都道府県の人材動向を把握する。

\section{II. 調査分析の対象と方法}

\section{1. 調査分析対象}

本研究では, 全国的な傾向を捉えるべく 47 都道府県の 担当部署を対象とし，担当部署にアンケート調査を実施し た。表-1に示す通り, 県・環境税を導入している 37 府県 のうち, 過半の 24 府県では県環境税と環境譲与税を同一 の部署が所管し，13 県では異なる部署の所管となってい る。ただし, 部署間のすみ分けは単純ではなく, 使途によっ ては別の部署の所管となることや, 県へ配分される環境譲 与税については異なる部署の所管となるケース等がある。

\section{2. 調査分析方法}

分析に用いたデータは, 各都道府県の担当者への質問票 調査及び対面・電話での聞き取り調査において取得している。

表-1. 調査対象とした県環境税及び環境譲与税の担当部署一覧

\begin{tabular}{|c|c|c|c|}
\hline & \multirow[t]{2}{*}{ 都道府県 } & \multicolumn{2}{|c|}{ 担当部署 } \\
\hline & & 主に県環境税 & 主に環境譲与税 \\
\hline & 岩手県 & 農林水産部林業振興課 & 同一 \\
\hline & 宮城県 & 環境生活部 環境政策課 & 水産林政部 林業振興課 \\
\hline & 秋田県 & 農林水产部森林整備課 & 同一 (木材利用分野：林業木材産業課) \\
\hline & 山形県 & 農林水産部森林ノミクス推進課 & 環境エネルギー部 みどり自然課 \\
\hline & 福島県 & 農林水産部森林計画課 & 同一 \\
\hline & 茨城県 & 農林水产部林政課 & 同一 \\
\hline & 杤木県 & 環境森林部環境森林政策課 & 同一 \\
\hline & 群馬県 & 環境森林部森林局 森林保全課緑化推進係 & 森林環境部森林局＼cjkstart林政課 \\
\hline & 神奈川県 & 環境農政局緑政部＼cjkstart水源環境保全課 & 環境農政局緑政部 森林再生課 \\
\hline & 富山県 & 農林水产部森林政策課 & 同一 \\
\hline & 石川県 & 農林水産部森林管理課 & 同一 \\
\hline & 山梨県 & 森林環境部森林環境総務課 & 同一 \\
\hline & 長野県 & 林務部森林政策課 & 同一 \\
\hline & 岐阜県 & 林政部 恵みの森づくり推進課 & 林政部 林政課 \\
\hline & 静岡県 & 経済産業部森林・林業局森林計画課 & 同一 \\
\hline & 愛知県 & 農林基盤局林務部＼cjkstart森林保全課 & 農林基盤局林務部 林務課 \\
\hline & 三重県 & 農林水产部 みどり共生推進課 & 農林水产部 森林·林業経営課 \\
\hline & 滋賀県 & 琵琶湖環境部森林政策課 & 同一 \\
\hline 県環境税 & 京都府 & 農林水産部 森の保全推進課 & 同一 \\
\hline \multirow[t]{22}{*}{ 導入有り } & 大阪府 & 環境農林水産部森づくり課 & 同一 \\
\hline & 兵庫県 & $\begin{array}{l}\text { 農政環境部農林水産局豊かな森づくり課、県土整備部 } \\
\text { まちづくり局都市政策課 }\end{array}$ & 農政環境部農林水産局 林務課 \\
\hline & 奈良県 & 農林部森林整備課 & 同一 \\
\hline & 和歌山県 & 森林・林業局 森林整備課 & 森林・林業局 林業振興課 \\
\hline & 鳥取県 & 農林水産部森林づくり推進課 & 農林水产部林政企画課 (基金部分：森林づくり推進課) \\
\hline & 島根県 & 農林水産部林業課 & 同一 \\
\hline & 岡山県 & 農林水産部林政課 & 同一 \\
\hline & 広島県 & 農林水産局 森林保全課 & 農林水産局 林業課 \\
\hline & 山口県 & 農林水産部 森林企画課 & 同一 \\
\hline & 愛媛県 & 農林水産部森林局森林整備課 & 同一 \\
\hline & 高知県 & 林業振興·環境部 林業環境政策課 & 同一 (県への配分：林業振興・環境部森づくり推進課) \\
\hline & 福岡県 & 農林水产部＼cjkstart林業振興課 & 同一 （県への配分：複数課） \\
\hline & 佐賀県 & 農林水産部林業課 & 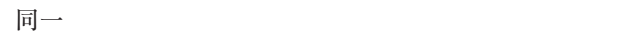 \\
\hline & 長崎県 & 農林部林政課 & 同一 \\
\hline & 熊本県 & 農林水産部森林局森林整備課 & 同一 \\
\hline & 大分県 & 農林水産部＼cjkstart森との共生推進室 & 農林水産部 林務管理課 \\
\hline & 宮崎県 & 環境森林部環境森林課 & 同一 \\
\hline & 鹿児島県 & 環境林務部環境林務課 & 環境林務部森林経営課 \\
\hline & 北海道 & & 水産林務部森林計画課 \\
\hline & 青森県 & & 農林水産部林政課 \\
\hline & 新潟県 & & 農林水产部林政課 \\
\hline & 埼玉県 & & 農林部森づくり課 \\
\hline 県環境税 & 東京都 & & 産業労働局森林課 \\
\hline \multirow[t]{5}{*}{ 導入無し } & 千葉県 & & 農林水産部森林課 \\
\hline & 福井県 & & 農林水産部県産材活用課 \\
\hline & 徳島県 & & 農林水産部スマート林業課 \\
\hline & 香川県 & & 環境森林部みどり整備課 \\
\hline & 沖縄県 & & 農林水産部森林管理課 \\
\hline
\end{tabular}


具体的な調查内容は, J-Stage 電子付録付表-1の質問票に 示す通り，環境譲与税と県環境税の間のす久分けと，市町村 支援のあり方としての情報交換のための会の設置, 人事交流, ガイドラインの策定の状況である。本研究で活用するデー夕 を取得した調査の時期は，2020 年 3〜 7 月である。情報交換 のための会の設置状況（J-Stage 電子付録付表-1 質問票にお ける「市町村との連絡」の項目）については，2019 及び 2020 年度の両年度で同様の質問項目による調查を実施した。

また，市町村との情報交換のための会の設置状況，人事 交流，ガイドラインの策定状況に照らして，環境譲与税と 林業, 林野, 市町村の分布に関する基本的な指標として, 配分される䛨与額と, 木材生産産出額, 私有林人工林面積 率，市町村数との関係性の分析を行う。情報交換のための 会の設置は円滑な連携を行うための手段であるが，そのよ うな会を設置していること自体が，情報交換を積極的に推 進しようとする姿勢や連携の活性度合いを反映している可 能性がある。そのため, それらの姿勢や具体的な人事交流, ガイドラインの策定による支援について，袞与額や林業の ポテンシャル等との関係性について, 初期的な分析を実施 した。なお，同関係性の分析では，譲与額または木材生产 産出額が極端に少ない/多いグループ A， B，D の北海道， 東京都，神奈川県，大阪府，香川県，沖縄県を除いた 41 府県を対象とした。

\section{III. 調査分析結果}

\section{1. 環境譲与税の府県への配分分と県環境税の使途のす み分け}

以下では，環境譲与税の府県への配分分の主な使途につ いて, 四つの領域（物理的な森林整備支援，森林情報整備 支援，所有者・意向調查に関する情報整備支援，担い手育 成・普及啓発等）を対象に，県環境税と環境譲与税による 事業について如何なるすみ分けがなされているか，県環境 税を導入している 37 府県を対象に調査を行った結果を示 す。香坂・内山（2019）では県環境税の見直し状況の概要 についての調查結果が示されたが，本研究では，見直しの 有無に関わらず，両税について使途にどのようなすみ分け がなされているかを調査した結果を提示する。

1）物理的な森林整備（間伐・路網整備・流通等）

環境譲与税と県環境税による整備対象の森林を分類し て，対象森林レベルですみ分けを行うケースと，物理的な 森林整備をいずれかの税を基に実施するといった事業レべ ルですみ分けを行うケースが調查結果より把握された。具 体的には，対象森林レベルですみ分けを行う場合では，林 業経営に適さない森林を定義して抽出している場合や, 所 有者に管理意思がない森林を対象とする場合等がある。ま た, 針広混交林化に環境譲与税を活用するケースもある(栃 木県)。事業レベルですみ分けを行う場合では，一部の府 県 (岐阜県, 愛知県, 滋賀県, 大阪府, 和歌山県等) に扔 いては，間伐等の森林整備自体を府県に譲与された環境譲 与税を活用する事業の対象にしないという方針である。こ のように, 物理的な森林整備に対する環境譲与税と県環境 税のすみ分けの方法は, 府県によって大きく異なっている。
府県によって大きな違いがある背景には，すみ分けを行う 際に参照されるそもそもの県環境税自体の目的や使途が府 県によって異なっていることと, 林業経営に適する/適さ ない森林の定義を行う府県とそのような定義はせずに環境 襄与税を別の使途に活用する府県が存在すること等があ る。県環境税自体については, そもそも比較可能性が低い という根源的な限界があることを前提としつつも, 以上の 大まかな傾向が特定された。

\section{2）森林情報整備}

森林情報整備については, 過半の府県で環境譲与税を基 に実施されている。先述の結果で示した通り, 森林情報整 備を含む技術移転, 技術指導は, 環境譲与税を活用した事 業のうち予算額が最も大きい各府県の事業のなかでも，最 も多くの府県で害施されて扔り，予算という面からも，森 林情報整備は環境譲与税によって推進されている側面があ ると考えられる。

間伐などの物理的な森林整備と異なり, 特定の森林（手 入れ不足私有林人工林）のみを対象とすることは，特に森 林の航空レーザ計測等を行う際は非効率となる。具体的に は, 資源量の航空レーダによる計測では, 所有や経営の可 否の区分を考慮して計測を行うことは非効率であり，むし ろその計測結果が，前述のような区分の判断材料となる。 そのため, 森林情報整備については, 対象とする森林によっ てすみ分けを行うということは現害的ではないケースが多 いと考えられ, 実際, 森林情報整備については, 環境譲与 税のみを活用する方針が過半の府県で採用されている。

地理情報システム (GIS) については, 複数の都道府県 が連携するケースや，県境に位置する市町村が連携する ケース等に打いては, システムの互換性やデー夕の仕様の 標準化などが必要とされることも予想され，そのような ニーズに対しても環境譲与税が活用されて整備が進む可能 性がある。

3）所有者・意向調査に関する情報整備

市町村による所有者・意向調查に関する情報整備の支援 については, 森林情報の整備と同様, 県環境税では行わず, 環境譲与税をもとに実施する府県が過半となっている。森 林経営管理法に基づく市町村による意向調查の支援につい て府県配分分の環境譲与税が活用されている。府県によっ ては市町村による意向調查の対象森林について方針を示し ており, 例えば神奈川県のように, 県が指定する水源保全 地域で行われる事業のみを県環境税による意向調査の対象 とするといった対象によるすみ分けもなされている。対象 森林を設定して, 環境譲与税をもとに調査を行う森林を定 義して調査を実施することは, 上述の航空レーザ計測等と は異なり, 調査効率の面から大きな問題とならない可能性 がある。そのため, 対象とする森林によってすみ分けを行 う県も一定程度 (7 県: 福島, 神奈川, 山梨, 長野, 三重, 奈良, 福岡) 存在する。意向調查実施プロセスについては, 島根県のように, 市町村に新しい経営管理計画の一連の手 続きを早期に体験してもらうという意図から, 森林所有者 の意向調査からではなく, 地域の林業事業体から具体的な 提案を受けつけるプロセスから情報整備を進めている例も 
ある。

\section{4）担い手育成・普及啓発}

担い手育成・普及啓発についても，過半の府県で環境譲 与税をもとに実施されており，県環境税では行わない傾向 がある。ただし，対象となる森林や事業によっては県環境 税を活用して実施している府県もあり，結果的に担い手育 成・普及啓発については，16 県では，使途の重複を避け ながらも，環境譲与税と県環境税の両者を活用して事業が 実施されている。

\section{2. 連携状況 (情報交換のための会, 支援組織の設置状況)}

まず 2019 年段階における 47 都道府県と市町村の対面で の情報交換の場の概況を分析する。全 47 都道府県の $1 / 3$ 程度は管内を複数の圈域に分けて情報交換の場を設置して いる。圈域の分け方は，地域農林事務所等の出先機関の管 轄を基準にしていることが多い。また，2019年前後に新 規に連絡の場を設置したのは 19 府県であり，そのうち大 分県, 山口県, 徳島県等は 2018 年より設置している。全 体の 3 割にあたる 14 都県では, 県下の市町村が置かれて いる状況の多様性から，個別の情報交換を重視するといっ た姿勢 (奈良県等) がみられ，そもそも集合体として市町 村との定期的な対面での情報交換の場が設置されていな かった。この比率は, 県環境税の有無には大きく影響され ていないと考えられる（県環境税・導入県の $1 / 3$, 非導入 県の $1 / 4$ が上記情報交換の場の設置がなかった)。

情報交換の場は，市町村支援の場でもある。市町村向け の支援の形態については，都道府県によって大きく三つの パターンがあった。具体的には，（i）新たに支援を目的と した組織体（センター・協議会等）を設置する形態，（ii） 既存の農林事務所・振興局及び連絡会等がその空口や議事 に支援を追加する形態，（iii）経営管理計画並びに環境讓 与税の連絡会は特になく，個別に市町村と相談する形態に 分かれた。さらに 2019 年の前後で形態が地域ごとに細分 化するパターン（大分県：全県での統一的な制度説明から 事務所単位) と, その逆のパターン (山口県) も確認された。

以上の連携パターンにおいて, 大多数の都道府県 (14 県) では，県一市町村，市町村同士の連携は既存のものが活用 されているのが害情である。反面，新しい動きとして，新 規に市町村の連絡を促す仕組みを県が提供しているパター ンがある。具体的には，愛知県は 2019 年から環境譲与税 に特化した，県が主催する市町村の協議会を設置している （日本林業調査会 2019）。宮城県においても類似した動きが ある。その他, 秋田県, 富山県, 長野県, 島根県において もセンターを設置して市町村の支援を行っている(表-2，3）。

なお，表-2において市町村に対して個別に対応してい る場合は「個」，既存の会議体を活用して議題等に新規に 追加している場合は「既」，新たに会議体を設置した場合 は「新」と記入している。会議体名の空欄の県は，会議体 を設定せずに対応していることを示す。また，表中の北海 道以下は，森林整備のための県環境税を導入していない都 道県である。

\section{3. 人事交流}

人事交流においては，都道府県と市町村の間において，
表-2. 情報交換の会議体の設置状況

\begin{tabular}{|c|c|c|}
\hline 県名 & 会議名称 & 形態 \\
\hline 岩手県 & $\begin{array}{l}\text { ※県庁に森林経営管理制度対策チーム設置 (2019), 県 } \\
\text { 庁一出先機関の連絡会議 }\end{array}$ & 個 \\
\hline 宮城県 & 森林経営管理制度推進会議（圈域推進会議）（2019） & 新 \\
\hline 秋田県 & $\begin{array}{l}\text { 県·市町村全県連絡会, 各地域振興局·市町村連絡会, } \\
\text { 町村会副町村長研修会 }\end{array}$ & 既 \\
\hline 山形県 & $\begin{array}{l}\text { 山形県森林管理推進協議会 (全県) - 山形県森林管理推 } \\
\text { 進協議会地域協議会 (4 地域) (2019) }\end{array}$ & 新 \\
\hline 福島県 & & 個 \\
\hline 茨城県 & 連絡調整会議（2019） & 新 \\
\hline 栃木県 & とちぎ森林管理推進協議会 (2019) & 新 \\
\hline 群馬県 & 林業県ぐんま推進会議, 実務者会議（2019） & 新 \\
\hline 神奈川県 & 県・市町村等担当部課長会議 & 既 \\
\hline 富山県 & & 個 \\
\hline 石川県 & 森林バンク推進協議会 （地域協議会）（2019） & 新 \\
\hline 山梨県 & 会議（名称無し） & 個 \\
\hline 長野県 & 連絡会議（広域連携） & 個 \\
\hline 岐阜県 & & 個 \\
\hline 静岡県 & 地域連絡会（環境讓与税用）（2019） & 新 \\
\hline 愛知県 & 「あいちの森づくり」県・市町村連絡調整会議（2019） & 新 \\
\hline 三重県 & 地域協議会, 連絡会議, 意見交換会 & 既 \\
\hline 滋賀県 & 森林整備協議会 & 既 \\
\hline 京都府 & 森林経営管理ワーキング (2019) & 新 \\
\hline 大阪府 & 森づくりサポート協議会＋不定期の説明会（全市町村） & 既 \\
\hline 兵庫県 & 管内市町担当者会議 & 既 \\
\hline 奈良県 & 会議（名称無し） ※基礎自治体への個別対応を重視 & 個 \\
\hline 和歌山県 & 各出先機関に押いて実施する市町村林務担当者会議 & 既 \\
\hline 鳥取県 & $\begin{array}{l}\text { ※森林環境譲与税の有効活用と森林環境保全税の使途検 } \\
\text { 討プロジェクチーム設立 (2019) } 7 \text { 市町 (鳥取市, 若 } \\
\text { 桜町, 智頭町, 倉吉市, 三朝町, 米子市, 日南町) と県 } \\
\text { が参加 }\end{array}$ & 新 \\
\hline 島根県 & 基礎自治体ごとの協議会設立（2019） & 個 \\
\hline 岡山県 & 岡山県森林経営管理制度連携推進会議 (2019) & 新 \\
\hline 広島県 & 地域調整会議（市町毎） & 既 \\
\hline 山口県 & $\begin{array}{l}\text { 新たな森林管理システムの円滑な運用等に関する協議の } \\
\text { 場（2018） }\end{array}$ & 新 \\
\hline 愛媛県 & & 個 \\
\hline 高知県 & 林業事務所ワーキング (2019) & 新 \\
\hline 福岡県 & 市町村個別相談会 & 個 \\
\hline 佐賀県 & & 個 \\
\hline 長崎県 & 担当者説明会等 & 個 \\
\hline 熊本県 & $\begin{array}{l}\text { 新たな森林経営管理制度及び森林環境譲与税（仮称）説 } \\
\text { 明会 }\end{array}$ & 個 \\
\hline 大分県 & 森林環境譲与税連絡調整会議（2018） & 新 \\
\hline 宮崎県 & & 個 \\
\hline 鹿児島県 & 担当者会 & 既 \\
\hline 北海道 & 森林環境譲与税に関する市町村等説明会等 & 既 \\
\hline 青森県 & 担当者会議 & 既 \\
\hline 埼玉県 & $\begin{array}{l}\text { 森林経営管理制度及び森林環境譲与税に関する会議や研 } \\
\text { 修会 }\end{array}$ & 既 \\
\hline 千葉県 & 千葉県森林管理連絡調整会議（2018） & 新 \\
\hline 東京都 & 森林環境譲与税担当者会議 (2020) & 新 \\
\hline 新潟県 & 会議（名称無し） & 既 \\
\hline 福井県 & $\begin{array}{l}\text { 地域協議会 (2019) } \\
\text { 森林環境譲与税の使途等に係る打合せ会 (2018) }\end{array}$ & 新 \\
\hline 德島県 & とくしま森林経営管理協議会 (2018) & 新 \\
\hline 香川県 & 市町・森林組合担当者打合せ会 $(2019)$ & 新 \\
\hline 沖縄県 & 林業研究会 & 既 \\
\hline
\end{tabular}


表-3. 支援センターの設置状況

\begin{tabular}{|c|c|c|c|c|c|}
\hline 県名 & 名前 & 設置年 & 箇所・ブロック数 & 単位 / 場所 & 備考 \\
\hline 宮城県 & $\begin{array}{l}\text { サポートセンター } \\
\text { (宮城県林業公社内) }\end{array}$ & 2019 年 4 月 & 7 & $\begin{array}{l}\text { 地方振興事務所単位 (地域事務 } \\
\text { 所含む) : 大河原, 仙台, 北部, } \\
\text { 栗原, 東部, 登米, 気仙沼 }\end{array}$ & 一社）宮城県林業公社内に設置 \\
\hline 秋田県 & 森林経営管理支援センター & 2019 年 4 月 & 3 & $\begin{array}{l}\text { 県北(北秋田市), 中央(秋田市), } \\
\text { 県南 (横手市) }\end{array}$ & \\
\hline 富山県 & 森林経営管理支援センター & 2019 年 4 月 & $\begin{array}{l}\text { 本庁 } 1 \\
\text { センター } 4\end{array}$ & $\begin{array}{l}\text { 魚津 (名称は新川農林振興セン } \\
\text { ター), 富山, 高岡, 研波 }\end{array}$ & \\
\hline 長野県 & 森林経営管理支援センター & 2019 年 4 月 & $\begin{array}{c}1 \\
\text { (会議体数：10) }\end{array}$ & 地域振興局単位 & \\
\hline 島根県 & 森林経営推進センター & 2019 年 4 月 & 1 & $\begin{array}{l}\text { 基礎自治体単位で地域協議会を } \\
\text { 設置して対応 }\end{array}$ & $\begin{array}{l}\text { 森林経営管理制度は, 森林経営推進セン } \\
\text { ターと県㕂森林整備課が対応, 森林環境譲 } \\
\text { 与税は県庁林業課が対応。 }\end{array}$ \\
\hline 愛媛県 & 森林管理支援センター & $\begin{array}{l}2019 \text { 年 } 8 \text { 月 } \\
\text { (以降各センター } \\
\text { を設置) }\end{array}$ & $\begin{array}{c}5 \\
\text { (設置済みは 2) }\end{array}$ & $\begin{array}{l}\text { 中予, 東予, 南予の森林管理推 } \\
\text { 進センター, 肱川流域活性化セ } \\
\text { ンター, 中予山岳流域林業活性 } \\
\text { 化センター }\end{array}$ & $\begin{array}{l}\text { 設置済み: 南予森林管理推進センター, 中 } \\
\text { 予山岳流域林業活性化センター } 2020 \text { 年 } 8 \\
\text { 月設置予定 : 中予森林管理推進センター } \\
2021 \text { 年 } 4 \text { 月設置定定 : 東予森林管理推進 } \\
\text { センター 検討中 : 肱川流域活性化セン } \\
\text { ター }\end{array}$ \\
\hline
\end{tabular}

森林経営計画制度・森林環境譫与税導入を契機とした人事 交流が害施されたかどうかの概況を把握した。林政担当部 署における人事交流自体は，10 府県で実施されている。 森林経営計画制度導入を契機とした交流であると明確な回 答を得られなかったものを含めて 2018～2020 年より交流 が開始されており，制度導入が府県と市町村の連携を人事 レベルでも促していることが示唆された。交流の形態とし ては，府県側から職員を派遣するケースと市町村側から府 県に派遣するケースに加え, 相互に派遣を行っているケー スもあった。

特徵的な事例として, 愛媛県が独自に併任制度を導入し ており，県の普及員でありながら同時に市町村の職員を併 任している。県環境税を導入していない県（徳島県など） に打いても県と市町村との交流が開始された事例がある一 方で，導入と同時に交流が終了する例（埼玉県・秩父市） もあった。

なお，表-4では，2018～2020 年より交流が開始された 府県の情報を提示しているが，2019年の森林経営計画制 度と環境譲与税の施行の前から，人事交流を実施している 事例は多数あり, 岐阜県, 広島県, 島根県, 山口県, 鹿児 島県等で林政担当部署における人事交流がなされている。 岐阜県と長野県については相川（2020）で調査分析がなさ れている。市町村に, 県職員 OB を派遣する事例も多数ある。

各府県が交流を行っている市町村数は, 最大 5 自治体(愛 媛県), 過半が 1 程度である。導入されて日が浅いこと もあり, 本研究では交流の有無と形態のみの調查にとど まった。将来の研究においては，人事交流の効果と示唆を 考察するために, 新制度導入時の交流の意義や効果を定性・ 定量の観点から検証していくことが必要となる。同時に, 今後は, 都道府県と市町村の垂直連携に加え, 事務局の共 同運営など市町村同士の水平連携等の事例もでてくること が予想される。

\section{4. 環境讓与税・森林経営管理制度の活用のためのガイ ドラインの策定状況}

独自のガイドラインについては，環境譲与税の使途に関
表-4. 人事交流の状況

\begin{tabular}{|c|c|c|c|}
\hline 県名 & 開始年度 & 人数 & 派遣·人材交流 \\
\hline 茨城県 & $2019, \quad 2020$ & $\begin{array}{c}2 \\
\text { (各 } 1 \text { 名) }\end{array}$ & 大子町, 常陸太田市 \\
\hline 山梨県 & 2019 & 1 & (一社 ) 山梨県森林協会市町村支援部 \\
\hline 長野県 & 2020 & 1 & 木曽広域連合 (自治法に基づく団体) \\
\hline 静岡県 & 2019 & 1 & $\begin{array}{l}\text { 富士市（相互に派遣） } \\
\text { ※他に小山町への派遣実績が以前よ } \\
\text { りあるが同町への派遣職は森林環 } \\
\text { 境譫与税に関する業務を担当しない。 }\end{array}$ \\
\hline 京都府 & 2019 & 1 & $\begin{array}{l}\text { 福知山市（府へ職員（一般事務職） } \\
\text { を } 1 \text { 名派遣。森林経営管理制度・森 } \\
\text { 林環境讓与税の分野を担当） }\end{array}$ \\
\hline 和歌山県 & 2018 & 1 & 田辺市（相互に派遣） \\
\hline 愛媛県 & 2020 & $\begin{array}{c}10 \\
(\text { 各 } 2 \text { 名) }\end{array}$ & $\begin{array}{l}5 \text { 市町村 [四国中央市, 東温市, 久 } \\
\text { 万高原町, 大洲市, 鬼北町 ] (県職 } \\
\text { 員が併任の形で派遣) }\end{array}$ \\
\hline 高知県 & $\begin{array}{l}2018,2019 \\
2020\end{array}$ & 各 1 名 & $\begin{array}{l}\text { 香美市（2018）梼原町（2019）越智 } \\
\text { (2019) 佐川町（2020） }\end{array}$ \\
\hline 大分県 & 2019 & 1 & $\begin{array}{l}\text { 中津市（相互に派遣）（ただし環境 } \\
\text { 譲与税に特化せず） }\end{array}$ \\
\hline 徳島県 & 2019 & 1 & 那賀町（県へ派遣） \\
\hline 埼玉県 & & 1 & (2019 年度まで＼cjkstart県から秩父市へ派遣) \\
\hline
\end{tabular}

するものと,森林経営管理制度に関するものに大別される。 後者については，2018 年 12 月に国レべルにおいて林野庁 が「森林経営管理制度に係る事務の手引」を発表している が, その国のガイドラインの発表以前の時期に, 独自に森 林経営管理制度のガイドラインを策定した事例もみられる。

森林経営管理制度を対象としたガイドラインは 12 府県 で策定されており, 環境譲与税のガイドラインは 8 県(宮城, 神奈川, 福井, 三重, 兵庫, 大分, 福岡, 熊本) で策定さ れている。それらの府県のうち, 宮城県, 神奈川県, 熊本 県については, 両方のガイドラインを策定している。大分県, 神奈川県についてはガイドラインの公表もしている。また, 長野県は森林経営管理制度を対象に包括的な「市町村業務 マニュアル」等を策定している。以上より, 森林経営管理 制度と環境譲与税のいずれかについてガイドラインを策定 
している府県は，計 17 府県である。他に，現在策定中の 県もあった。また，森林経営計画制度と環境譲与税の二領 域にまたがるかたちで策定されている事例もあった。

ガイドラインの公表については，大分県のように，「大 分県森林環境譲与税ガイドライン」（2019 年 4 月制定, 2020 年 1 月改正）を公表している例もあるが，都道府県 独自に策定されたガイドラインは，市町村向けの資料とし て，林業関係者を中心とした範囲に限定した情報公開と なっているケースが多い。

ガイドラインの策定自体については，「市町村からの要 望を受けて」策定というケースもある。一方で「市町村に 譲与されたものなので県策定のガイドラインはそぐわな い」とする（九州エリア担当者）都道府県もあり，市町村 への関与については判断が分かれている。

環境譲与税と県環境税の使途の整理については，税の手 引きとして独立させず，森林経営計画制度のマニュアルに 含めた形（宮城県等）で説明している場合もある（表-5）。

5. 連携, 人事交流, ガイドライン策定と都道府県の特 徵との関係性

市町村との情報交換のための会の設置状況，人事交流， ガイドラインの策定状況について，4指標（配分される譲 与額, 木材生産産出額, 市町村数, 私有林人工林面積率) との関係性を，策定の有無によって府県を区分してぞれぞ れの指標の平均值を算出して平均值の差の検定 ( $t$ 検定 $)$ を行うことで分析を行った。なお，本分析においても，変
与額及び木材生産産出額が極端に少ない/多いグループ A, B, D の北海道, 東京都, 神奈川県, 大阪府, 香川県, 沖縄県を除いた 41 府県を対象として分析を行っている。

まず，情報交換のための会の設置状況（設置有り：29, 設置無し：12）については, 設置している県と未設置の県 の平均值について, 市町村数, 私有林人工林面積率の 2 指 標に統計的に有意な差があることが検定によって把握され た（いずれも $p<0.1$, 市町村数 : $t=1.476$, 私有林人工林 面積率 : $t=1.348)$ 。具体的には, 会を設置している場合で は, 市町村数が多く, 私有林人工林面積の割合も高かった。 このことは, 市町村数が多く, 県レベルで情報交換を積極 的に促す必要のある場合や, 環境譲与税の対象となる私有 林人工林面積の割合が高い地域では, 県レベルでも譲与税 の活用に関する指導等を情報交換の場を設定して行う傾向 にあることを示唆している（図-2）。

人事交流については，交流を行っている場合（10 県） と行っていない場合（31 県）に関して, 譲与額のみ有意な 差がみられた $(p<0.1, t=1.305)$ 。交流を行っていない場 合の平均譲与額は約 7,800 万円で, 交流を行っている場合 は約 9,200 万円であった。このことは，人事交流実施の背 景に, 譲与額の多鿒が影響している可能性を示唆している。 ガイドラインの策定状況についても，策定を行っている 場合（16 県）と行っていない場合（25 県）について, 譲 与額のみ有意な差がみられた $(p<0.05, t=2.107)$ 。行っ ていない府県の平均譲与額は約 7,300 万円で, 行っている

表-5. ガイドラインの策定状況

\begin{tabular}{|c|c|c|c|}
\hline \multirow[t]{2}{*}{ 県名 } & \multicolumn{2}{|c|}{ 独自ガイドライン・マニュアル・冊子 } & \multirow[b]{2}{*}{ 時期 } \\
\hline & 森林経営管理制度 & 環境譲与税 & \\
\hline 宮城県 & 森林経営管理制度の運用及び森林瓄 & 境譲与税の使途に係るガイドライン & 2019 年 3 月 \\
\hline 栃木県 & 森林経営管理制度運用マニュアル & & 2019 年 5 月 \\
\hline 神奈川県 & 森林環境譫与税を活用した森林管理に関するガイドライン & $\begin{array}{l}\text { 神奈川県における森林環境譫与税の取組方針 } \\
\text { ・神奈川県の市町村における森林環境譲与税を活用した木材 } \\
\text { 利用に関するガイドライン }\end{array}$ & 2019 年 4 月 \\
\hline 長野県 & 森林経営管理制度市町村業務マニュアル & & 2020 年 4 月 \\
\hline 岐阜県 & 森林経営管理制度に関する市町村事務マニュアル & & 2019 年 4 月 \\
\hline 三重県 & & 譲与税の使途 & 2019 年 2 月 \\
\hline 京都府 & 森林経営管理法に基づく森林経営管理ガイドライン & & 2019 年 3 月 \\
\hline 兵庫県 & & 兵庫県森林環境譲与税活用ガイドライン & 2018 年 12 月 \\
\hline 島根県 & $\begin{array}{l}\text { 市町村職員が制度運用の流れに沿った事務を行うためのマ } \\
\text { ニュアル* }\end{array}$ & & 2020 年 3 月 \\
\hline 山口県 & 森林経営管理制度に係る事務マニュアル & & 2019 年 2 月 \\
\hline 愛媛県 & 新たな森林管理システム移行調査等ガイドライン & & 2020 年 3 月 \\
\hline 高知県 & 森林経営管理制度の県独自のマニュアル & & 2019 年 4 月 \\
\hline 福岡県 & & 森林環境譲与税ガイドライン & $\begin{array}{r}2019 \text { 年 } 3 \text { 月 } \\
\text { 改訂 }: 2020 \text { 年 } 3 \text { 月 }\end{array}$ \\
\hline 熊本県 & 森林経営管理制度に関する取組事例集 & 森林環境袞与税に関する使途事例（市町村向け） & 2020 年 1 月 \\
\hline 大分県 & & 大分県森林環境譫与税ガイドライン & $\begin{array}{r}2019 \text { 年 } 4 \text { 月 } \\
\text { 改訂 : } 2020 \text { 年 } 1 \text { 月 }\end{array}$ \\
\hline 鹿児島県 & 森林経営管理制度の業務マニュアル & & 2020 年 3 月 \\
\hline 福井県 & & $\begin{array}{l}\text { 福井県森林環境謮与税ガイドライン } \\
\text { (一部、経営管理制度の内容を含む) }\end{array}$ & 2019 年 12 月 \\
\hline
\end{tabular}

*島根県：一連の事務手続きを早期に市町村に体験してもらいたいとの考えから, 地域の林業事業体から具体的な森林の提案を受け付け制度を進めるとい う手法を提案。※群馬県 : 会議資料の提供, 長崎県 : 策定中。 

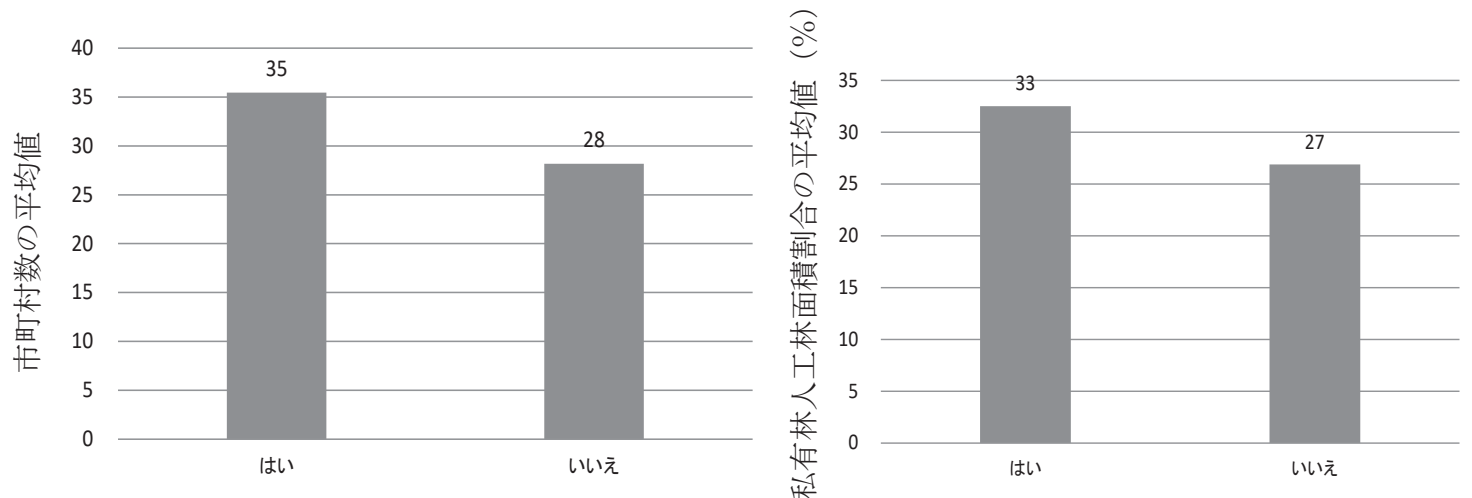

図-2. 市町村との情報交換のための会の設置状況（はい：設置有り，いいえ：設置無し）と市町村数（左のグ ラフ), 総森林面積における私有林人工林面積の割合（右のグラフ）の平均值（対象 : 北海道, 東京都, 神奈川県，大阪府，香川県，沖縄県を除く 41 府県）

総森林面積については, 林野庁の「都道府県別森林資源現況 (平成 29 年 3 月 31 日現在)」を, 私有林人工林面積については, 同じ く林野宁の「市町村別私有林人工林面積（平成 29 年 3 月 31 日現在）」のデータを参照した。

府県は 9,300 万円であり，一定の差がみられた。ただし， 譲与基準のなかでも私有林人工林面積, 林業就業者数など の要素が影響し，意向調查，集積計画等に向けたガイドラ インの策定のニーズが市町村に高かった可能性もある。大 分県では市町村からの要望でガイドラインを策定した経緯 がある。

\section{IV. 結論}

市町村レベルでは税の受け皿として計画の推進役を担う 林務の専門的知識を有する職員が不足している一方で，こ れまで地域の林政において主要な役割を担っていた都道府 県も市町村を主対象とした譲与税について, 市町村への指 導のあり方を模索している。また各都道府県で, 県環境税 の有無も含め, 状況が大きく異なる。本研究では, その各 都道府県の概況と, 複数の税を導入している府県における 整理を分析した。

本研究では, 都道府県を対象として, (1)環境譲与税と県 環境税の間のすみ分け，(2)連携状況（情報交換のための会, 支援組織の設置状況), (3)人事交流, (4)ガイドライン, (5)連携，人事交流，ガイドライン策定と都道府県の特徽と の関係性の概況を明らかにした。

(1)のすみ分けについては, 都道府県によって対応が異な る事業項目としては物理的な森林整備が把握され，二税両 方の活用がなされる事業項目としては，担い手育成・普及 啓発，所有者・意向調査に関する情報整備等があった。以 上のように環境譲与税と県環境税の活用のあり方は, 都道 府県間で多様性と同時に類似性もみられる。森林や林業に 類似性のある都道府県間で情報共有を進めるべく，各都道 府県の担当部署や議会等に扔いて情報共有を行うことは今 後の使途の検討において有用である可能性がある。

調査では, 府県によっては環境譲与税に特化した活用ガ イドラインを作成し，すみ分けについて対照表を作成して， 整理しているケースも把握された。また，対象森林の設定 や，担い手育成に扔けるすみ分け等について，対象森林の 詳細な定義を検討している府県もあるため, 森林整備や担 い手育成等の各政策項目に抄けるすみ分けの詳細な分析は
今後の課題である。また, すみ分けの方法等について考察 していくうえで, 府県内の担当部署や担当者の役割の分析 も課題となる。本稿は概要を提示しているが, 各県・環境 税については 5 年に一度見直される傾向があり（大阪府等 は 4 年ごと), 使途の整理に関する議論を予定している府 県も存在することからも, 各府県に扔いて掘り下げた研究 が待たれる。

市町村支援のあり方に関わる(2)〜 (4)について全都道府県 に共通する傾向はあまりみられず，都道府県によって対応 が分かれている状況が把握された。例えば，(2)の県による 支援形態については, 独自センターを設置して対応する事 例（6 県）等が把握された。(3)人事交流については, 都 道府県と市町村の双方から職員を派遣するパターンや, 独 自に併任制度を導入するパターン（愛媛県）等も特定され た。(4)のガイドラインの策定については，17 府県におい て森林経営管理制度または環境譲与税のガイドラインが策 定されているものの, ガイドラインの策定自体に対する姿 勢や公開に対する姿勢にも差異がみられた。特に, 環境譲 与税については,「譲与」という形式に対して都道府県の 姿勢は分かれ，ガイドラインを策定して指導を進めるパ ターンと, 讓与という性質を重視し, 使途等について市町 村の裁量に委ねるべく，ガイドラインの策定はせずに市町 村を支援するパターンが把握された。

ただし，(2)〜 (4)のいずれも, 都道府県の対応は刻々と変 化して扔り, 譲与額や林業・林野等に関する特徴が異なる 都道府県に打いても，相互に参照されるべストプラクティ ス等が蓄積されることによって, 将来的には人事交流等に おいて一定のスタンダードが形成される可能性もあると考 えられる。

本研究に打いては, (5)の「連携, 人事交流, ガイドライ ン策定と都道府県の特徵との関倸性」についても 4 指標を 基に考察を行った。結果, 情報交換の会の設置状況につい ては, 市町村数や私有林人工林面積率と相関がみられ, 人 事交流及びガイドラインの策定状況については, 氈与額と の相関が把握された。それらの結果から, 情報交換の会の 設置状況は, 譲与額の多寊に関わらず，府県のコンテクス 
トに起因する必要に応じて実施されている可能性があり, 人事交流及びガイドラインの策定については，譲与税が取 り組みを後押ししている可能性が考えられる。

今後は，インターネット上で市町村や都道府県における 使途の公開がなされていく。冒頭で述べたように，税の導 入・運営に際して,「森林の公益的機能」は納税者（国民・ 県民・市民）の理解が得られやすい反面，各層における税 の使途と役割や機能の整理が重要となるなかで, 初年度の 概況を示した本研究は，今後の分析の基礎的資料ともなり うる。今後, 環境譲与税と県環境税の使途のすみ分けが行 われ，都道府県による市町村支援が実施された結果，どの ような効果が得られたのかという点も, 当初の気候変動へ の対応という大きな目的と照らし合わせ，都市部も含めて 検証する必要がある。ただし，森林整備や人材育成等につ いては短期的な効果が得られにくい領域であるため，中長 期的な評価を行う必要があり，その評価枠組みの設計や時 系列の情報の蓄積等の準備を進めることも求められる。

\section{謝辞}

本研究での調査分析の遂行において多大なるご協力をいただいた対 象 47 都道府県, 林野庁, 総務省の御担当者の皆様に, この場を借りて 感謝の意を表する。本調査の質問票後に, 電話やメール等による補足調 査にもご協力いただいた。な戈，本研究は下記研究の一環として実施さ れた; MEXT/JSPS 科研費 JP16KK0053, JP17K02105, 20K12398, JST • RISTEX 科学技術イノベーション政策のための科学研究開発プログラム （課題名：農林業生産と環境保全を両立する政策の推進に向けた合意形 成手法の開発と実践 [JPMJRX20B3，代表：香坂＼cjkstart玲）。

\section{引用文献}

相川高信（2020）都道府県による市町村支援．林業経済 72(10)：3-15 秋山孝臣 (2005) 森林環境税とその森林環境および林業における意義. 農林金融 58(2): 32-45

青木卓志・桂木健次（2008）森林環境税の地域への影響．富大経済 論集 53(3): 531-554

青木卓志（2014）森林環境税導入の政策過程の一考察．地域学研究 44(1): 81-95

淺田陽子・阿部達生（2020）森林環境譲与税：新たな税制度が都道 府県・市町村の森林行政に与える影響とは(1) (都道府県編)，政 策研究レポート，三菱UFJリサーチ＆コンサルティング株式会 社（https://www.murc.jp/wp-content/uploads/2020/11/seiken 201112 pdf：閲覧日 2020 年 11 月 19 日)

番場哲晴 (2004)「森林環境税」と水源地域の保全. 自治研究 80(6)：7388

Bespyatko L・井村秀文（2008）環境サービスに対する支払いとして の森林環境税に関する研究．環境科学会誌 21(2)：115-132

古川 泰（2004）流域再生に向けた森林へのあらたな環境支払い 農業と経済 70(7): 31-38

花岡千草（2011）森林環境保全のための新たな財源化についての一 考察. 地域学研究 41(2): 449-465

今若慎太郎・佐藤宣子（2008）「森林環境税」による新たな森林整備 に関する研究，九州大学農学部演習林報告 89: 75-126

石崎涼子（2019）森林環境税における受益と負担．環境情報科学 48 (1): $43-48$

石崎涼子（2010）水源林保全に抢ける費用分担の系譜からみた森林 環境税. 水利科学 54(5): 46-65

柿澤宏昭（2018）日本の森林管理政策の展開 その内実と限界，日 本林業調查会. 238

木村憲一郎（2016）県民の意向を反映した森林環境税の運用に関す る一考察。林業経済研究 62(2): 1-10

木村憲一郎（2017）2000 年代以降における都道府県林務行政組織の 変容に関する実証的研究. 林業経済研究 63(3): 32-41

香坂 玲・内山愉太 (2019) 森林環境譲与税の導入と都道府県への 影響の分析一37 府県の概況について一．日林誌 101: 246-252

香坂 玲・大澤太郎・内山愉太 (2020）森林環境譲与税を介した都
市一農山村連携一埼玉県秩父市と東京都豊島区の事例から一. 日林誌 102: 127-132

松本美香 (2018) 深刻化する森林管理問題の解決に向けた三つの方策. （土地所有権の空洞化. 飯國芳明・程 明修・金 泰坤・松本充 郎編著, ナカニシヤ出版). 63-81

村上一真 (2011) 森林環境税制度受容の意思決定プロセスに関する 構造分析. 環境情報科学論文集 2: 101-106

日本林業調査会（2019）譲与税と独自課税の使途調整，愛知県・市 町村が連絡会議. 林政ニュース第 605 号 (2019 年 5 月 29 日発行) 西尾 隆（2018）自治の視点からみた森林・林業政策一森林管理は 市町村の責務か権利か, (自治体森林政策の可能性一国税森林環 境税・森林経営管理法を手がかりに，自治総研ブックレット 22. 飛田博史編，公人の友社). 35-54

農林水産省「平成 30 年 林業産出額」 (https://www.maff.go.jp/j/tokei/ kouhyou/ringyou_sansyutu/：閲覽日 2021 年 1 月 5 日）

岡田久仁子 - 岡田秀二 - 由井正敏 (2007) 森林環境税形成過程に関 する研究「いわての森林づくり県民税」検討委員会の分析を中 心に. 東北森林科学会誌 12(1): 1-11

大石太郎・立福家徳 (2013) 目的税としての環境税への支払意思とソー シャル・キャピタルーネット調査を用いた実証研究—. 福岡工 業大学研究論集 46(2): 83-87

大谷基道（2017）都道府県における新たな政策に係る人材の確保一 出向官僚と民間人材の活用一. 公共政策研究 17: 69-82

林野庁「都道府県別森林資源現況 (平成 29 年 3 月 31 日現在)」 (https:// www.rinya.maff.go.jp/j/keikaku/genkyou/h29/3.html：閲覧日 2021 年 1 月 5 日)

林野庁「市町村別私有林人工林面積（平成 29 年 3 月 31 日現在）」 (https://www.rinya.maff.go.jp/j/keikaku/genkyou/h29/7.html：閲覧日 2021 年 1 月 5 日)

佐藤大樹・山本美穂（2013）栃木県「森林環境税」における普及啓発 活動の現状と課題一宇都宮市内小学校へのアンケート調查を通 して．宇都宮大学農学部演習林報告 49: 61-68

清水雅貴（2019）国税・森林環境税の問題点（第 4 回）国税・森林 環境税の導入による府県・森林環境税への影響について。自治 総研 45(8): 1-13

曹預（2015）PESの視点から見た森林環境税及び水源基金の課 題—愛知県の事例検討を中心に, 水資源 - 環境研究 28(1)：75-81 総務省（2019）令和 2 年度税制改正の大綱（令和元年 12 月 20 日 閣 議決定).

総務省「令和元年度 森林環境譲与税 袞与額」(https://www.soumu. go.jp/main_sosiki/jichi_zeisei/czaisei/04000067.html：閲 覧日 2021 年 1 月 5 日)

鈴木春彦・柿澤宏昭・枚田邦宏・田村典江（2020）市町村に扔ける 森林行政の現状と今後の動向：全国市町村に対するアンケート 調査から，林業経済研究 66(1)：51-60

多田忠義（2020）森林環境譲与税の執行環境に関する速報と地域差 分析の試み。農林金融 73(1): 33-53

田家邦明（2018）「新たな森林管理システム」と森林政策上の意義. 農業研究 31: 203-255

田家邦明（2019）森林環境税の活用に向けた課題．農業研究 32: 267296

高橋卓也（2005）地方森林税はどのようにして政策課題となるのか： 都道府県の対応に関する政治経済的分析．林業経済研究 51 (3): 19-28

竹本 豊（2009）高知県での森林環境税導入における政策決定過程 分析．林業経済研究 55(3)：12-22

高井 正 (2005)「森林環境税」の論点と住民自治. 都市問題 96 (7)：6981

飛田博史（2019）国税森林環境税・譲与税創設の経緯とその問題点 自治総研 487: 1-49

内山愉太・香坂 玲（2020）政令指定都市における森林環境譲与税 の活用の現沉：都市部における森林政策の多様な展開の分析. 日林誌 102: 173-179

Uchiyama Y, Kohsaka R (2016) Analysis of the distribution of forest management areas by the forest environmental tax in Ishikawa prefecture, Japan. Intern J For Res 2016: 1-16

山谷清志（2005）外務省大臣官房の政策管理機能 - 総合外交政策局 とのすみ分け．年報行政研究 2005(40)：24-46

吉弘憲介（2020a）譲与基準の分析から明らかになる国税・森林環境 税の問題点と, 本来あるべき森林整備財源の配分基準. 本地方 財政学会研究叢書 27: 115-133

吉弘憲介 (2020b) 森林環境税をどう考えるか一一森林環境税の理論 と実態に関する試論。都市問題 111(2)：63-72 